and that in this, as in so much else, the Church has led the way, for Samuel Crowther was himself an African and the work once begun by missionaries from overseas is increasingly being carried out by the men and women of Nigeria themselves.

\title{
East African Institute of Social Research Conference, June I957
}

THE following papers were given at the East African Institute of Social Research's summer conference: Social class in modern Buganda, by L. A. Fallers; The rise of the Uganda African Farmers' Union in Buganda, by A. B. Mukwaya; The report of the Income Tax Commission, by David Walker; Regional disparities of income and taxation in Uganda, by W. Elkan; Some problems of change amongst the Kuria, by M. J. Ruel; A history of relations between the Arusha and the Masai, by P. H. Gulliver; Recent researches amongst the Masai, by Alan H. Jacobs; The structure of Shambalai, by E. V. Winans.

\section{Sierra Leone's first Festival of Arts}

THE festival of arts held in Freetown in December revealed and encouraged the creative talents of the people of Sierra Leone in a wide variety of crafts, ranging from carving, weaving, dyeing, and leatherwork to tribal dancing. Sir Gordon Russell, Director of the Council of Industrial Design, lectured and adjudicated in some of the competitions. During the festival Sierra Leone's Museum was officially opened. Among its exhibits are the crown of Paramount Chief Jaia Kaikai I, a statute of Madame Yoko (Paramount ruler of the Kpa Mende from 188 , to 1906), and the original Royal Charter of 1799 which gave Freetown its mayor.

\section{Lamu and the East African Dhow Traffic}

DR. A. H. J. PrINs, Reader in Cultural Anthropology in the State University of Groningen, Netherlands, has just completed a six months' study of the social and economic organization of the East African dhow trade and its implications for the population of the Lamu Islands off the coast of northern Kenya. This is the first modern analysis of one of the Islamic coastal communities, the study of which was judged to be urgent and long overdue in a recent assessment of current and necessary research in East Africa (see Africa, xxvi. 3, 1956, pp. 271, 275). Before embarking on this study in May, Dr. Prins also had an opportunity to visit the Persian Gulf area, with which the African coast is most intimately connected by the seasonal traffic of the ocean-going dhows. Part of the results of the present field study will be incorporated in his forthcoming section on the Swahili, which is to appear in the Institute's Ethnographic Survey series. The Lamu study, together with Professor Grottanelli's researches among the Northern Bajun, also an important component of the population of the Lamu area, means that up-to-date material on the northern part of the coastal civilization will now be available. Moreover, Dr. P. Lienhardt is at present engaged in field research among the Arabs of Zanzibar, and Dr. G. Wilson, the Kenya Government sociologist, has completed his social survey of Mombasa town. It may therefore be expected that our knowledge of an African culture area so long neglected will shortly be enlarged to a very considerable extent.

[Communicated by Dr. A. H. J. Prins]

Researches at I.R.S.A.C.

A stuDY of the history of Ruanda and Urundi is being undertaken by M. Jan Vansina in co-operation with M. l'Abbé Kagame. M. A. A. Trouwborst, who is due to arrive at I.R.S.A.C. in January, is to study the political structure of Urundi, with special reference to 